\title{
Islamic Education With Multicultural Insight An Attempt Of Learning Unity In Diversity
}

\author{
Farid Hasyim, M.Ag \\ Fakultas Ilmu Tarbiyah dan Keguruan (FITK), \\ Universitas Islam Negeri Maulana Malik Ibrahim \\ Jalan Gajayana, Kec. Lowokwaru, Kota Malang, Jawa Timur, Indonesia 65144 \\ Tel: (62) 341-551354 Fax: (62)341-572533 email: faridhasyim.uin@gmail.com
}

\begin{abstract}
Education has a vital role in smartening up human life; it is not surprising that the way to measure the quality of a civilization is determined by the quality of its educators. In the modern and heterogenic era as today, education with multicultural insight is required in order to give understanding about the importance of unity and diversity, so it is expected that there will be no more violence in the name of race, ethnicity, culture and even religion. Islam is often perceived as a harsh, exclusive and sectarian religion, whereas Islam is full of moral values, compassion, tolerance and inclusion. In response, Islamic education is required to give an understanding to the world that Islam is a religion that respects multiculturalism. This is where Islamic education with multicultural insight must be present in order to explain the relationship between man and God (hablun min Allah, theological aspects); the relationship of unity, namely human relationships with others (hablun min al-nas, anthropo-sociological aspects); and human relationship with the natural surroundings (hablun mi al-'Alam, cosmological aspect).
\end{abstract}

Keywords: Islamic Education; Multicultural; Unity; Diversity

\section{Introduction}

In general, education is frequently reviewed as an individual phenomenon on the one hand and as a social phenomenon on the other. The first view is based on an anthropological perspective with an understanding of human beings as a reality (microcosmic) with basic potential ownership that can be developed in the future, and in Islam viewpoint it is often called 'fitrah' or nature, (Abdurrahman anNahlawiy, 1989), that is a spiritual potential that is likely to evolve (developable). If the view of basic education is focused on internal human orientation, then the next view is directed to external orientation in the development of culture as a real condition of education. (Ahmad Janan Asifudin, 2009) This point of view, a measure of the educational process, is how education provides a conducive atmosphere for the development of human culture ethos, so that in real life a person can interact in his environment. In this sense education is defined as the process of and socialization and habituation of the values that flourish in the society.

Education in Islam not only pays attention to the individual because humans are social beings. That is why education should pay attention to the social and cultural aspects of learners in order to create leaders, scholars, craftsmen and individuals who can contribute to the society. (Asifudin, 2009) In this modern era individualistic lifestyle affects people's lives, so reexamination of the content of Islamic education and understanding relevant to the era is needed.

\section{The Values of Islamic Education}

Islamic education is an educational activity that is established, organized and implemented on the basis of aspiration, intention and motivation to translate the teachings and values of Islam through educational activities. (Iskandar, 2003) 
In accordance with the Koran, Islam religion has the universality of values that becomes a dynamic and harmonious guideline in life, and it is in line with the ideals of Islam, namely rahmatan lil alamin. Therefore, education should be able to raise the future life of people inspired by faith and righteous deeds. Islamic education should be able to bear a power that is loaded with three correlated values, i.e (a) dimension of faith that can subdue human dignity as Allah creation having the highest degree with virtue of the mind that distinguishes human from other creatures, (b) dimension of soul and Islamic view of life that brings the ideals rahmatan lil 'Alamin, (c) dimension of progresssion that will make human contemplate all justice and changes.

In the realization of these values, the formulation of strategic and educative Islamic education is required, that is an education that can integrate these values.

Islamic education we know it today is often conflicting with the Islamic values themselves (universality) whose orientation is more accentuated within the vertical-normative framework. In this case, Islamic education has not been able to actualize its dimensions (dimension of divinity, dimension of humanity, religious/normative, social, cultural, and others). Al-Attas explained the purpose of education in Islam is religious, religion not only has personal attribute, but inherently it is also social and cultural. (Syed M. Naquib Al-Attas, 2003) Thus Islamic education should be able to contextualize its teachings in life. In addition, the goals of monotheism education should be drawn in cultural formulation, not doctrinal or structural. (Abdul Munir Mulkhan, 2005)

As it is known in the world of education, there are two educational functions that should be performed. The first is normative function and the second is a dynamic progressive function (Rasmianto, 1996). The first function in question is that education is limited to the transfer of value in accordance with previous value. This function gives more emphasis on traditional education functions as culture conservator. The second function is dynamic progressive education development. The development of this function is as a logical consequence of education as a system that is open and struggles in the mainstream of society changes.

From these two functions we can observe that Islamic education is not only on normative level, but more important is the application in public life, especially in the future.

Society which consists of various individuals clearly has differences, whether from social, cultural, racial, ethnical or economic background. We know that Indonesia consists of various ethnicities, races, languages and others which are very valuable assets, and thus those aspects can not be separated in the education world which acts as a formal organization for children to get education and noble values. Therefore, multiculturalism based education is an attempt to provide an understanding of the diversity and the equality of local cultures. (James A. Bank, 1993) Given that educational institutions in the New Order stored many heartbreaking files, ideal education should be able to act as spokesman for the creation of multicultural life fundamental which is free of cooptation from the State. But in reality, educational institution is no more than an effective means of ideological-political unification in order to preserve power. Education paradigm based on uniformity of socio-cultural identity of the New Order has proven unable to sustain nationality multiculturalism that is genuine and authentic. The fall of the New Order was marked by a variety of social upheaval which raised primordialism of local identity. Ethnic conflict (in Sambas and Sampit) and interreligion conflict (in Maluku and Poso), the loss of East Timor from Indonesia and other social upheavals become the most valid proof of how fragile the multiculturalism-based nationality construction is, which so far has not proportionally understood. (Nasikun, 2005) Meanwhile, the paradigm of multiculturalism 
justifies the understanding that social and cultural elements of the nation should be inclusive, open up to other elements on the outside, and dare to have dialogue with others. (Masdar Helmy, 2003)

There are at least three groups of viewpoints that usually develop in addressing identity differences in relation to conflict that often arises. The first is primordialist point of view. The group considers that differences derived from genetics such as ethnic, race (and religion) are the main source of conflicts of interest between ethnicity or religion. (Clifford Geertz, 1973) The second is instrumentalist point of view. According to them, ethnic, religion and other identities are considered as a tool used by individuals or groups to pursue bigger goals, both in the form of material and non-material. This conception is more widely used by politicians and elites to gain support from identity group. By chanting "Islam" for example, it is expected that all Muslims will assemble to back up one's political interests. Therefore, in the view of the instrumentalist, as long as everyone is willing to concede to the preference desired by the elite, clashes between identity groups can be avoided. The third is constructivist, who argues that the identity of the group is not as rigid as what primordialist has imagined. For this group ethnicity can be processed to form a network of relationships of social interaction. Therefore, ethnicity is an essential source of wealth owned by people to know each other and enrich the culture. For them, similarity is a grace and difference is a blessing. (Anthony D. Smith, 1991)

In the context of the third opinion, there is a discourse on multiculturalism and multicultural education as a means to build tolerance for diversity. This discourse started to be popular in academic circles, cultural practitioners and activists in early 2000 in Indonesia.

It is inevitable that the system of theology developed in educational institutions does not allow understanding of proportional multiculturalism paradigm due to distortions. (Smith, 1991) The first distortion, religious doctrines are often used as a justification for interreligious conflict. Exclusivism phenomenon still strongly influences the curriculum of religious education in schools. Second, education in Indonesia tends to promote truth claims rather than truth exchange. The material taught at school only justifies what is believed to be true and judges what is believed to be wrong. The truth which they believe is then made absolute. The third, the developing realm is cognitive, not yet affective and psychomotor. This means the material transmitted to the students only impact on the addition of mere knowledge, but it has not been able to be internalized into the deepest consciousness system to be objectified into real behavior. In this respect education has a moral responsibility.

\section{The Basic Concepts of Multiculturalism}

Multiculturalism is a concept where community in diversity is a concept that can reduce vertical and horizontal conflicts in a heterogeneous society where the demands for recognition of the existence and the uniqueness of the culture of an ethnic group are very common. A multicultural society is able to provide a broad space for various identity groups to carry out autonomous life, thus creating a culture system and an established social order in a society that will become a pillar of peace of a nation. (Choirul Mahfud, 2006)

The concept of multicultural education in the countries that embrace democratic concepts such as the United States and Canada is not something new. They have been implementing multicultural education, especially in their efforts to eliminate racial discrimination among white skin and black skin, which aims to promote and maintain national integrity. (Gollnick, M.Donna, and Philip C. Chinn, 1998)

The multiculturalism etymology was adopted in the 1950s in Canada. According to the Longer Oxford Dictionary the term "multiculturalism" 
is a derivation of the word "multicultural". This dictionary cites a sentence from a Canadian newspaper, Montreal Times, that depicts Montreal community as a "multicultural and multi-lingual" society. (Muhaemin El-Ma'hady, 2004) With the above ideas, a living perception will be formed in a society that culture is not an absolute aspect that must be maintained. Culture would be understood as a movement of people's creativity built by the movement of different principles (revisiting) which then forms a mutual agreement about values, views, and attitudes (reinventing). It means culture grows and evolves with the development of society itself, which is certainly influenced by external factors that surrounds its life.

The existence of anarchism relates to demand for recognition of ethnic or self identity which is generally caused by the absence of such awareness. A culture grown in a community is seen as an absolute whose existence must be recognized and exalted. Such exaggeration then provides vast opportunities for people to vilify and not recognize the existence of other cultures. At this point we need a wise and prudent policy to provide vast opportunities for each cultural entity while recognizing the existence of other cultures. Otherwise, friction that occurs between cultures will be stuck on fanatical-exclusive attitude, which will certainly cause disunity. (Ahmad Hufad, 2007)

According to Parekh in his article entitled National Culture and Multiculturalisme (Bhikhu Parekh, 2003), he clearly distinguishes five kinds of multiculturalism. Obviously the division of the five forms of multiculturalism is not impermeable, but it can overlap in certain aspects: first, multiculturalism isolationist which refers to the community in which various cultural groups live autonomously and are involved in a minimum interaction to one another. Second, multiculturalism accommodative, is a plural society having a dominant culture, which makes adjustments and accommodations for the needs of cultural minorities. Third, multiculturalism autonomists, is a plural society in which the main cultural group tries to realize equality with the dominant culture and expects an autonomous life within a political framework which is collectively received. Fourth, critical or interactive multiculturalism, is a plural society where groups are not overly concerned with an autonomous cultural life; but rather require the creation of a collective culture that reflects and asserts their distinctive perspectives. Fifth, cosmopolitan multiculturalism, is a concept that tries to abolish cultural boundaries altogether to create a society where every individual is no longer tied to a particular culture. Instead, they are free to engage in intercultural experiments and to simultaneously develop each cultural life.

\section{The Foundations of Multicultural Education in Islam}

In doing any action it should be based on a proper foundation. This means that the foundation will make sure that everything is implemented in accordance with the rules, especially in developing a concept of education. In Islam the main foundation is the Koran and al-Hadith, so anything a Moslem does must not conflict with these two bases, similarly in multicultural education.

Multiculturalism is explicitly stated in the Koran verse in Surah Al-Hujurat, 49:13, namely:

"O mankind, indeed We have created you from male and female and made you peoples and tribes that you may know one another. Indeed, the most noble of you in the sight of Allah is the most righteous of you. Indeed, Allah is Knowing and Acquainted." QS. Al-Hujurat / 49: 13)

There are several things that can be understood from the verse above. First, the sentence in the above verse describes the chronological flow of human life. In Al-Maraghi interpretation it is mentioned that what is meant by "male" is Adam and "female" is Hawa. (Ahmad Mustafa Al-Maraghi, 1988) While in Al-Azhar interpretation it is mentioned that dzakakarun which means male is interpreted by Hamka 
with the intrinsic meaning man himself, and untsa which means female is also interpreted intrinsically as woman herself. Both meanings are analogous to that no human being is created except from a coition between a man and a woman, an intercourse that causes the encounter of sperm-drop and egg (Khama) into one for 40 days, which is named after nuthfah. Then in 40 days it becomes a clinging clot, and in another 40 days it becomes flesh. After 3 rows of forty days nuthfah, 'alaqoh and mudghah, it becomes a human whose soul is blown into him and then born into the world. (Hamka, 1982)

In the next sentence it is mentioned that the word $s y u$ 'ub in the above paragraph has a meaning of a major tribes having a lineage to a common ancestor. (Hamka, 1982) In Ibnu Kathir interpretation, it is explained that the word syu'ub has a more common meaning than the word qabail (tribes). But there is also a statement that what is meant by syu'ub is a resident of another country. Looking at this interpretation, from history human is basically the same in terms that they are from the same clay, namely from Adam and Hawa'. (Ibn Kathir, 2000)

Thus in the context of the above verse Allah reminds men that they are basically the same in terms of humanity. What sets them apart is the quality of piety, so the different level is in terms of the religious obedience to Allah and obedience to His Messenger. (Hamka, 1982) And it is reconfirmed in the verse above that man is made into people and tribes, so it is intended that a small group is not to grow further, but to know each other (lita'arafu). People can know where their origin is, where the base of the ancestors is, and from where their previous descent is. There is no distinction between one another and there is no need to evoke or reveal the difference, but to be aware of the similar descendant.

Based on the above theological basis, Islamic education must be based on and must also direct humans to three patterns of functional relationships, namely the religious relationship, namely the relationship between man and God (hablun min Allah, theological aspects); unity relationship, namely human relationships with others (hablun min al-nas, anthroposociological aspects); and human relationship with the natural surroundings (hablun mi al'Alam, cosmological aspect).

\section{The Main character and Dimension of Multicultural Education}

Multicultural education does not only include ethnic or racial issues. Both issues are raised in multicultural education, but more than that it also emphasizes on other issues such as gender relations, socio-economic diversity, religious difference and so on.

The view that multicultural education is taught as a separate material is a misconception. This misconception can be straightened out through discussion of four approaches which will be described more specifically in the following sub-topics.

Multicultural education stems from the attention of a US education expert Prudence Crandall (Husniatus Salamah Z, 2013) who intensively spread views about the importance of learner's background, in terms of culture, ethnicity, and religion aspects.

Multicultural education according to Dickerson (Zakiyuddin Baidhawy, 2005) is a complex education system that includes an attempt to promote cultural pluralism and social equality; a program that reflects the diversity of the entire area of the school environment; staffing pattern that reflects the diversity of society, teaches unbiased material and inclusive curriculum; ensures the equality of resources and programs for all students as well as the same academic achievement for all students.

Similar ideas appeares with many names, among others: multicultural education (for Britain and North America), intercultural education (Europe 
in general), peace education (Africa and Asia), Community understanding (Wales), citizenship education (UK), Social, civic and political education (Republic of Ireland), and personal and social education (United Kingdom).

In the context of religious education the main characteristics described by Zakiyuddin Baidhawy (2005) are: 1) learning to live in diversity. All this time conventional education rests on three pillars, how to know, and how to be. Conventional education has not fundamentally taught and embedded "the skill of living together" in a plural life in terms of religion, culture and ethnicity. The fourth pillar is very important, namely how to live and work together with others. The embedding of the fourth pillar - as an complementary connection to the other three pillars which include process, developing tolerance, empathy and sympathy, and clarification of common life values according to religious perspective. Emotional maturation is a complex thing that requires openness and freedom, equality in participation, new social contract or rules in inter-religious life, 2). Mutual trust, is the most important social capital in the cultural strengthening of civil society. Too cautious to perform contract, transaction, relationship and communication with outsider (other religions and their followers) can build up suspicion which can lead to tension and inter-religion conflict, 3). Mutual understanding (nurturing mutual understanding), signifies that to understand does not necessarily mean to agree. Mutual understanding is the awareness that their values and ours can be different and can perhaps complete each other and contribute to the dynamic and lively relationship, 4). Mutual respect, upholding mutual respect, respecting and appreciating others are universal values contained by all religions in the world, 5). An open thought, the important purpose of education is the maturity of thought, 6). Appreciation and interdependence, a humanitarian life can be created in a caring social order, where all people are able to show appreciation and maintain relationships, attachment, social cohesion and close involvement, 7). Non-violent conflict resolution and reconciliation, in conflict situations, religious education must be present to inject the spirit and spiritual power as a means of integration and social cohesion. It also acts as fresh wind for peace and reconciliation. However, the resolution of conflict is not yet sufficient without reconciliation, namely an effort to make peace through the means of forgiveness because forgiveness in conflict situation is an appropriate action. (Baidhawy, 2005)

Dimensions in multicultural education (ElMa'hady, 2004);

\section{a. Integration Content}

Integrating different cultures and groups to illustrate basic concepts, generalizations and theories on any subjects/discipline.

\section{b. The Knowledge Construction Process}

Bringing students to understand the implications of culture into a subject (discipline)

\section{c. An Equity Pedagogy}

Adjust teaching methods to student learning method in order to facilitate the diversity of student's academic achievement in racial, cultural or social aspect.

\section{d. Prejudice reduction}

Identifying the racial characteristics of students and determining the teaching methods

e. Training groups to participate in sport, interacting with the entire staff and students of different race and ethnicity in order to create an academic culture.

In any educational activity, learners are the target (object) as well as the subject of education. Therefore, to understand the nature of learners, educators need to include an 
understanding of the general characteristics of the learners. In general, students at least have five characteristics, namely; learners have the power to use their ability, willingness, and so on. Learners have an aspiration to grow toward adulthood. Learners have different backgrounds. Learners explore the surrounding nature with the basic potential owned individually. (Nana S. Sukmadinata, 1995).

According to Tilaar, (HAR Tilaar, 2004) multicultural education begins with the development of the notion and awareness about "interculturalism" after World War II. In addition to being related to international political developments concerning human rights, freedom from colonialism and racial discrimination, and others, the emergence of "interculturalism" idea and awareness is associated with increasing plurality in the Western countries as a result of an increasing number of migrations from newly independent countries to America and Europe.

Regarding the focus of multicultural education, Tilaar reveals that in multicultural education program, the focus is no longer directed solely to racial groups, religions and cultural domains or mainstream. Such focus was once the prominence of intercultural education that emphasized on an increased understanding and tolerance among individuals who came from minority groups against the dominant mainstream culture, which in turn made people from minority groups integrated into the mainstream society. Multicultural education is actually an attitude of "care" and wiling to understand (difference), or "politics of recognition" (Tilaar, 2004).

In that context, multicultural education sees community in greater context. Based on the basic view that the attitude of "indiference" and "non-recognition" is not only rooted in the inequality of racial structure, but the paradigm of multicultural education includes subjects about injustice, poverty, oppression and underdevelopment of minority groups in various fields: social, culture, economy, education and so forth. Such paradigm will encourage the growth of "ethnic studies" and later to find its place in the educational curriculum from primary level to higher education. (Mahfud, 2006) The core purpose of the discussion of this subject is to achieve empowerment for minority and disadvantaged groups.

From the description above, we can see that in religious education with multicultural insight, to instill awareness of the importance of living together in diversity and religious differences with the spirit of equality and parity is to find the best way to resolve conflict between religions and create peace by means of forgiveness and non-violence action.

Development of multicultural religious education can be done in three ways: (Baidhawy, 2005) a) the realm of curriculum, reference and learning material; $b$ ) the realm of learning method oriented on student's diversity; and c) the realm of social learning environment of the school or the students. Meanwhile, here is the explanation of how multicultural education can be implemented in religious education in schools and universities in Indonesia. This explanation is very important, especially for educators and policy-makers in general, and stakeholders as a start in making choice on multicultural education.

\section{Orientation of Multicultural Education}

Content orientation can be developed in several ways, borrowing four frames of JA Banks, there are several approaches on curriculum reform: (Banks, 1993) First, contributive approach is an approach that has the least involvement in multicultural education reform. This approach is done by selecting required or suggested text books. In the context of religious education, the main purpose of contributive approach on the content of curriculum is to include materials about the diversity of religious, cultural and ethnic groups in education and in the subject of education with the aim to increase students' 
knowledge about the diversity of those groups. In its simplest form it can be done by combining a small multicultural reading in face to face meeting, and in commemoration of religious holy days.

Second, the additive approach in this content oriented program takes the form of contents, concepts, themes and perspectives into the curriculum without changing its basic structure. With additive approach, religious education utilizes typical multicultural content as enrichment in teaching materials; the concepts of harmony and inter-religious life can be the icebreaker in respond to the existence of other religions. The enrichment of this perspective can arouse student's sensitivity in observing religious indications and their development in the society.

Third, transformative approach that attempts to actually change the structure of the curriculum and encourage students to look at and review concepts, issues, themes and old problems, then renew their understanding from various perspectives and ethnicity viewpoints. A sophisticated version of the curriculum conducts transformation with the goals: developing curriculum through various disciplines; combining various viewpoints and diverse perspectives in the curriculum; and transforming, particularly developing a new paradigm for the curriculum. The application in religious education means creating a new curriculum in which the concepts, themes and problems that become the content of the curriculum is approached by comparison approach.

Fourth, social action approach which combines transformative approach with activities that seek to make social changes. In this context, religious education does not simply instruct students to understand and question social issues, but it also does something important with regard to the issue.

Geneva Gay added one stage of multicultural educational development through deconstructive approach. This approach is often understood as a criticism, a discharge as well as reconstruction of knowledge by education theoreticians. According to him, the stage of the deconstruction directs teaching and learning towards an effort to nurture students to become a skeptical healthy person, who is constantly questioning existing claims against the truth as well as social and academic accuracy in order to evaluate new explanation, and to determine that various ethnic and cultural group perspectives are represented; and that pluralistic knowledge, perspectives and experiences are used as criteria to reexamine the premises and assumptions about the education system that has been long-running. Through deconstruction stage, learning activities are carried out in relation to cultural diversity issues and they can include measures to: a) clarify the biases created by human; b) determine which story is discussed and validated from which standpoint; c) engage in perspective taking, d) do introspection, reflection, and self renewal. (Geneva, 1995)

Fundamentally content orientation tends to utilize certain class management methodology, a methodology that is no longer centered on the teacher's authority as in traditional classroom.

In order to achieve changes in the curriculum, we can adopt the measures offered by Banks and Mclntosh, (Banks, 1993), and then adapt them to religious education with multicultural insight as follows. First, giving criticism and reviewing the exclusive curriculum of mainstream religious education. Exclusive curriculum usually ignores experience, voice, contribution and perspective of individual and minority religious groups in all material discussions. All educational materials, including textbooks, films, slides and other teaching and learning materials present one-sided information based on the format of religious mainstream understanding. This curriculum brings negative consequences for students of non dominant religious groups for failing to validate their culture, experience, and perspectives. 
Second, religious teachers "celebrate" difference by integrating information or sources of prominent people from various religious groups into the main curriculum.

Third, there are efforts to integrate major holidays and religious figures into the material substance and religious knowledge into the curriculum of religious education.

Fourth, materials, perspectives and new voices woven into new knowledge framework provide a new level of understanding of the curriculum of religious education which is more accurate and complete.

Lastly, in addition to the changes that occur in structural reforms, social issues such as racism, sexism, clasism in the name of religion are also introduced in the curriculum of religious education.

b) Student orientation. Multicultural education is an attempt to reflect the growing diversity of Indonesian society and in particular the diversity of the class. Many programs move beyond the existing curriculum to meet certain academic demand, namely careful efforts to define groups that grow within students, including minority groups. Student-oriented programs is intended to improve the academic achievement of these groups, although at that time they do not feel and do not engage in the extensive changes in the curriculum. This program is designed to help students culturally and religiously to make the transition into mainstream education. In this manner, the program needs to see the cultural and religious background of the students. By itself this program can take several forms: First, a program that uses a research about religious culture-based learning style in an effort to determine which teaching style will be used for certain groups of students, Second, cross-border program; inter-religious joint study, inter-ethnic joint study; a joint study between genders.

The first program requires a survey about the extent of the influence of religious culture to student's effective learning style. This survey supplies the teacher to perform cultural and religious classification or categorization. The result of classification or categorization becomes the basic materials to provide different treatment in accordance with the characteristics of student groups.

The second program focuses on the efforts of teachers to bring students to have direct interaction experience in diversity. For the sake of religious education, the learning process could perhaps be implemented through the creation of study groups which involve a series of students from different religious backgrounds and beliefs, ethnicities, and others.

Direct interaction cross ethnic-religion, culture, and gender will enrich student's religious horizon and reduce bias, stereotypes, and prejudice based on religious sentiments. They have the opportunity to clarify the distortion and manipulation of knowledge that have been growing and developing in their own thoughts, which may be inherited from generation to generation.

c) Social orientation. This program emphasis on efforts to reform schools and cultural context, politics of schooling that aim to bring a broad influence on the improvement of cultural, religious and ethnic tolerance and social prejudices that grow and take root in the society. This kind of orientation program includes programs designed to improve all forms of interreligions, inter-ethnic and inter-culture contact and encounter. The program provides support to minority groups in schools, eliminates biases that grow among people and impact on student communication, and emphasizes learning together. Such type of educational orientation emphasizes human relations in all forms, and combines some of the characteristics of two other orientations.

\section{Transformation of Education}

Multicultural education should be a 
transformational process, not just the process of tolerance. It means multicultural education is not just teaching about different cultures - cultures of various ethnic and religious groups- but it also supports appreciation, comfort, and tolerance to other cultures. As a transformational process, multicultural education presents as a process through all aspects of education which are tested and criticized and rebuilt on the basis of the ideals of equality and social justice; fosters all people of all cultures to become activists in facing injustice; constructs self identity recognized by a lot of people confidently; develops ways of interacting with others. (Banks, 1993) In this context, it is also necessary to carry out religious education with multicultural insight through a progressive approach that can be adapted to direct the entire programs in the transformation of education. Fundamentally, education is held to give influence and direction for social changes through the three-way transformation: First, self transformation, In line with the transformation of the curriculum, it is necessary to begin by considering which voices need to be heard and which not, and their valuable or valueless perspectives, all with the main focus and remains in resemblance. Transformation must begin by reconsidering and testing everything that interacts in the classroom which includes the value system, prejudice, experience, chosen learning style, and the way to ensure and influence each other in a learning community.

Psychological foundations of religious education with multicultural insight underline gives an emphasis on the development and transformation of wide understanding of oneself, positive self-conception, and modesty in religious, cultural and ethnic identity. In addition, selftransformation is related to individual attitude and behavior to the whole religious, ethnic, and cultural groups based on stereotypes, prejudice and racism. In the context of Indonesian people who contracted a disease called suspicion to one another, religious education with multicultural insight should help explain the attitudes and values of religions.
The second is school transformation. What makes school referred to as a multicultural community is the ability to manage diversity so that school lives in an environment full of diversity.

Attempt to make changes can be reached through two paradigms: first, the paradigm of tolerance characterized by an addition in the content of curriculum that does not change the assumptions and fundamental conceptualization of education. Paradigm of group tolerance is not identical in the context of cultural plurality. Both paradigm transformations seek to restructure school through a continuous process that involves all aspects of education, from curriculum to school culture. Cultural material is not taught in an educational unit that is separated from the regular curriculum, but fused in the entire territory of the academy, including religious education.

Another goal of school transformation is equality and egalitarianism. This transformation departs from the awareness and understanding that the excellence of education can not be achieved by any student when there is an elimination attempt against religious, ethnic and cultural group. This effort is built on the idea that equality is the key to providing equal educational opportunities to students with diverse religious, ethnic and cultural background. (Mahfud, 2006)

The third transformation is the social environment. The keywords understanding and conditioning inclusive social environment where all groups feel secure in difference and diversity, are not just about awareness and sensitivity to the cultures and ideas of others. It is the bravery to enter a shift in paradigm to see the world as an inclusive setting where everyone can benefit each other in diversity.

Within this framework, religious education with multicultural insight is directed to relieve tension by teaching communication across religions and relation intra-religion, understanding various perspectives and religious point of view, and 
understanding that the condition of the religions can influence values, attitudes, behaviors, beliefs, and expectations of the adherents.

In line with the goals of multicultural education to begin the process of change in schools, it will also extend to the community. This objective will be implemented by instilling attitudes, values, habits, and skills in students so that they can be the agents of social change who are committed to public reform with the aim to remove religious and ethnic disparities on social, economic, political and cultural occasion and implement this commitment. In this case, they need to improve knowledge on issues of religion and ethnicity while at the same time developing the ability to make decisions, social action skills, leadership capability, the sharpness in political view, and moral commitment to the dignity and the equality of humanity.

Social action approach focuses on oppression and social structure injustice with the intention to create a more empowered society and serve the needs and interests of all groups. This kind of education builds on student's personal empowerment by establishing the relevance of school learning and social life, providing practice in applying knowledge and taking action to direct their lives, and demonstrating the power of knowledge, collaborative attempts, and political actions that generate social change. (Banks, 1993)

Religious Education multicultural conception is not something taken for granted, but it requires a systematic effort that will actually create communities that are able to join in a community structure. Various efforts including orientation, the approach presented by Zakiyuddin Baidhawi are a concrete idea in realizing religious education with multicultural insight. But according to the author, there are very important things in realizing education with multicultural insight, namely teacher's ability of diversity knowledge and socio-religious issues. Therefore, before entering the realm of the content, students, and social, what is questionable is teacher's ability in transforming religious education with multicultural insight. Although teacher is not the authority, but teacher as a facilitator should be able to design learning and facilitate students' needs, including the need for knowledge of diversity, whether cultural, ethnic or religious. Thus in this case there must be a structural collaboration between teachers and the government as national policy maker.

\section{Conclusion}

Education is a vital tool in creating an atmosphere that is conducive to the development of human culture ethos, in other words, education is the most effective means to perform the transfer of knowledge about what is good and what is bad, so that human can become civilized beings. In a plural circumstance of life as in Indonesia, education must be present with a multicultural dimension in order to provide an understanding of the importance of unity and diversity to the people who often maintain their culture egoism.

In the Indonesian context, disintegration is one of the most dangerous threats, and one of the factors that could potentially cause disintegration of the nation is conflict in the name of religion. Sometimes we can see people or a particular religious community commit violence to another community just because of different views on certain issues. Considering that Indonesia is a country with the largest Muslim population in the world, Islamic education with multicultural insight is required to be present in order to inform the public that Islam is a religion full of moral values, affection, helping each other, tolerance, respect for diversity and other attitudes that uphold humanity.

The above values and attitudes do not necessarily thrive on their own. This is where educators are not only required to master and teach a subject professionally, but more than that, an educator must be able to instill multicultural values. These values must be trained and taught to younger generations in the national education 
system in order to realize peaceful and wealthy Indonesia.

\section{References}

Al-Attas, Syed M. Naquib. (2003). Filsafat dan Praktik Pendidikan Islam. Mizan, Bandung.

Al-Maraghi, Ahmad Musthafa. (1988). Tafsir Al-Maraghi. CV Toha Putra, Semarang.

An-Nahlawiy, Abdurrahman. (1989). Prinsipprinsip dan Metoda Pendidikan Islam, dalam Keluarga, di Sekolah dan di Masyarakat, terj. H.M.D. Dahlan dan H.M.I. Soelaeman. CV Diponegoro, Bandung.

Asifudin, Ahmad Janan. (2009). Mengungkit Pilar-Pilar Pendidikan Islam (Tinjauan Filosofis). UIN Suka Press, Yogyakarta, Indonesia.

Zakiyuddin, Baidhawy. (2005). Pendidikan Agama Berwawasan Multikultural. Erlangga., Jakarta.

Bank, J. A. (1993). An Introduction to Multicultural Education. Boston: Allyn and Bacon.

El-Ma'hady, Muhaemin. (2004). "Artikel Multikulturalisme dan Pendidikan Multikultural". Retrieved from www. PendidikanNetwork.co. id. 27 Mei.

Geneva, G. (1995). "Bridging Multicultural Theory and Practice" Multicultural Education 3(1).

Geertz, Clifford. (1973). The Integrative Revolution : Primordial Sentiment and Civil Politics in The New States. New York.

Gollnick, M. Donna, and C. Philip Chinn. 1998. Multicultural Education in a Pluralistic Society. New Jersey: Prentice Hall.

Hamka. Tafsir Al-Azhar. (1982). Jakarta: Pustaka Panjimas,
Helmy, Masdar. (2003). Menggagas Paradigma Pendidkan Berbasis Multikulturalisme, Jurnal Ulumuna, 7(12).

Hufad, Ahmad. (2008). Perilaku Kekerasan: Analisis Menurut Budaya dan Implikasi Edukatif. Jurnal Mimbar Pendidikan. No. 2/ $\mathrm{XXI} / 23$.

Katsir, Ibnu. (2000). Tafsir Ibnu Katsir. Sinar Baru Algesindo, Bandung, Indonesia.

Mahfud, C. (2006). Pendidikan Multikultural. Pustaka Pelajar, Yogyakarta, Indonesia.

Muhaimin. (2003). Arah Baru Pengembangan Pendidikan Islam. Nuansa, Bandung, Indonesia.

Mulkhan,Abdul Munir. (2005). Kesalehan Multikultural. Jakarta: PSAP.

Nasikun. (2005). Imperatif Pendidikan Multikultural di Masyarakat Majemuk. Makalah. Disampaikan di Universitas Muhamadiyah Surakarta.

Parekh, Bhikhu. (2007). "National Culture and Multi culturalism" dalam Kenneth Thomson (ed.). Media and Culture Regulation. London: Sage Publication.

Rasmianto. (1996). Keharusan Reorientasi Pendidkan Islam, Jurnal Tarbiyah, No 44, Tahun XIV: Oktober.

Salamah Z, Husniatus. (2013). Pendidikan Multikultural: Upaya Membangun Keberagaman Inklusif di Sekolah. diunduh di ft.sunan ampel .ac.id pada hari kamis, 6 September.

Smith, Anthony D. 1991. National Identity. Toronto: Penguin Books.

Nana, S. Sukmadinata. (1995). Psikologi Pendidikan. Bandung: PT Remaja Rosda Karya.

Tilaar, H.A.R. 2004. Kekuatan dan Pendidikan. Jakarta: Grasindo. 